\title{
Gas Chromatography-Mass Spectrometry (GC-MS) Analysis of Essential Oil salvia officinalis in Sudan
}

\author{
Amna Yousif Mohamed ${ }^{1}$, and Ahmed Ali Mustafa ${ }^{2 *}$ \\ ${ }^{1}$ Biotechnology Department, Faculty of Science and Technology, Omdurman Islamic \\ University, P.O.Box\#382, Omdurman Sudan. \\ ${ }^{2}$ Botany Department, Faculty of Science and Technology, Omdurman Islamic University, \\ P.O.Box\#382, Omdurman Sudan. \\ E.mail : ahmad.ali11526@gmail.com ${ }^{2 *}$
}

Tel: 00249911511696

\begin{abstract}
:
In this study the essential oils of Salvia officinalis growing in Sudan, were obtained by hydrodistillation and analyzed by Gas chromatography mass spectrometer, forty tow compounds were identified. The essential oil composition of S.officinalis found that it had many important compounds. The detected main compounds were oxygenated monoterpenes followed monohydrocarbone, squiterpenes and other compounds. The main essential oil constituents were $\alpha$-terpineol (33.07\%), camphor $(11.57 \%), \alpha$-pinene $(8.96 \%)$ camphene $(5.09 \%) \beta$-cymen $(5.40 \%)$ caryphyllene $(3.76 \%) \beta$-myrcene $(3.65 \%) \beta$-menth1en-b-ol (3.45\%) bomeol (3.38\%) $\beta$-pinene (2.74\%) Epiglobulol (2.59\%) 1,8 Cineol $(2.24 \%)$ and trans- $\beta$ - terpinyl butanone $(2.00 \%)$.
\end{abstract}

Keywords: Salvia officinalis, Essential oil, GC-MS, Sudan.

\section{Introduction:}

Medicinal plants are plants which contain substances that could be used for therapeutic purposes or which are precursors for the system of useful drugs [1]. The genus Salvia commonly called sage, is the largest member of lamiaceae or mint family containing over 900 species throughout the world [2]. Commonly known as garden or red sage, is a perennial hardy sub-shrub native to Mediterranean regions and is one of the most popular medicinal and culinary herb used in Arab world [3]. potential therapeutic activities of these a Salvia species are due to their essential oils [4].

Sage tea has been traditionally used for the treatment of digestive and circulation disturbances bronchitis, cough, asthma, angina, mouth and throat information, depression, excessive sweating skin diseases, and many other diseases. Salvia essential oils have been used in the treatment of a wide range of diseases like those of the nervous system, heart and blood circulation respiratory system digestive system, and metabolic and endocrine disease [5]. Essential oil of sage contains cineole, borneol and thujone. Sage leaf contains tannic acid, oleic acid, ursonic acid, ursolic acid, niacin, nicotinamide, flavones, flavonoid glycosides, cornsole, cornsolic acid, fumaric acid, chlorogenic acid, Caffeic acid, and estrogenic substances [6].

This study aimed to investigate the gas gromatography mass-spectrometer analysis for essential Oil Salvia officinalis growing in Sudan. 


\section{Material and methods:}

\subsection{Plant material:}

Sage (Salvia officinalis) aerial part was collected in February 2018, at Khartoum state, Sudan. Based on the available market samples brought from Syria. The identification of the plant material has been carried out at the Department of botany, faculty of science and technology, Omdurman Islamic University.

\subsection{Isolation of the oils Salvia officinalis:}

$1 \mathrm{~kg}$ of crushed sage was put in a Clevenger distiller apparatus. Then the sample was covered by distilled water. The temperature was adjusted at $66 \mathrm{C}$ and the condenser was attached. The extraction was carried out for 3 hrs. The mixture obtained was separated and the resulted oil was collected then it was treated with anhydrous sodium sulphate to eliminate all the water, and then stored in a refrigerator at approximately $4 \mathrm{c}$ until used.

\subsection{GC-MS analysis of the compound}

The constituents of the n-hexane extract and fractions were characterized and identified by GC/MS. GC/MS analysis were performed an a Shimadzu GC/MS-QP2010A system in ET mode (70ev ) equipped with a split /splitters injector $\left(250^{\circ} \mathrm{C}\right)$, at split ratio of $5 / 50 \mathrm{using}$ DB-5MSColumn (30m x 0.25mm id, film thickness: 0002E25 miss $\mathrm{J}$ and $\mathrm{W}$ scientific, fulsome, CA,WA ). Injection volume was 1 misarlitre and electronic pressure programming was used to maintain a constant flame $(0.67 \mathrm{ml} / \mathrm{mins})$ of the Helium carrier gas. The even temperature was programmed from $150^{\circ} \mathrm{C}(4 \mathrm{mins})$ to $320^{\circ} \mathrm{C}$ at a rate of $2 \mathrm{c} / \mathrm{mins}$ and held at than temperature $200^{\circ} \mathrm{C}$ and interface temperature $250^{\circ} \mathrm{C}$. The relative approach percentage of each compound was determined by area. Components idiidentification was carried out using the NIST 147 and NIST 27 libraries.

\section{Results and discussion:}

The components of the essential oil are summarized in (table 1). Analysis of the extract by GC/MS resulted in the separation of 42 compounds (Table 1). $\alpha$-terpineol $(33.07 \%)$ was the major component identified followed by camphor $(11.57 \%)$, $\alpha$-pinene $(8.96 \%)$ camphene $(5.09 \%) \beta$-cymen $(5.40 \%)$ caryphyllene $(3.76 \%)$ beta-myrcene $(3.65 \%) \beta$-menth1-en-b-ol $(3.45 \%)$ bomeol (3.38\%) $\beta$-pinene (2.74\%) Epiglobulol (2.59\%) 1,8 Cineol $(2.24 \%)$ and trans- $\beta$ - terpinyl butanone $(2.00 \%)$. According to the essential oils chemical composition of S.officinalis it was classified as $\alpha$-terpineol chemotype (33.07\%). According In 1990, Tucker et al. [7] categorized sage commercial oils in five chemotypes according to the amount of the major compounds: (i) camphor $>\alpha$-thujone $>1,8$-cineole $>\beta$-thujone; (ii) camphor $>\alpha$ thujone $>\beta$-thujone $>1,8$-cineole; (iii) $\beta$-thujone $>$ camphor $>1,8$-cineole $>\alpha$ thujone; (iv) 1,8-cineole $>$ camphor $>\alpha$-thujone $>\beta$-thujone; and (v) $\alpha$-thujone $>$ camphor $>\beta$-thujone $>1,8$-cineole. The chemical composition of the essential oil of sage of different regions in the Mediterranean basin such as the former Yugoslavia [8,9] Italy [10,11] Egypt [12] Morocco [13] and Tunisia [14]etc. 


\section{Table1. Gas Chromatography -Mass Spectrometer of S. Officinalis} essential oil:

\begin{tabular}{|c|c|c|c|c|}
\hline $\begin{array}{l}\text { Peak } \\
\text { NO }\end{array}$ & Compounds & R.T & Area (\%) & Formula \\
\hline 1 & $\alpha$-pinene & 4.846 & 8.96 & $\mathrm{C}_{10} \mathrm{H}_{16}$ \\
\hline 2 & camphene & 5.142 & 5.09 & $\mathrm{C}_{10} \mathrm{H}_{16}$ \\
\hline 3 & $\beta$ - pinene & 5.518 & 2.74 & $\mathrm{C}_{10} \mathrm{H}_{16}$ \\
\hline 4 & $\beta$-myrcene & 5.587 & 3.65 & $\mathrm{C}_{10} \mathrm{H}_{16}$ \\
\hline 5 & Sabinene & 5.664 & 0.15 & $\mathrm{C}_{10} \mathrm{H}_{16}$ \\
\hline 6 & terpinene & 5.872 & 0.22 & $\mathrm{C}_{10} \mathrm{H}_{18} \mathrm{O}$ \\
\hline 7 & 1,8 Cineol & 6.594 & 2.24 & $\mathrm{C}_{10} \mathrm{H}_{18} \mathrm{O}$ \\
\hline 8 & $\beta$-phellandrene & 6.670 & 0.18 & $\mathrm{C}_{10} \mathrm{H}_{16}$ \\
\hline 9 & $\alpha$-terpineol & 6.742 & 33.07 & $\mathrm{C}_{10} \mathrm{H}_{18} \mathrm{O}$ \\
\hline 10 & D-limonene & 7.036 & 0.37 & $\mathrm{C}_{10} \mathrm{H}_{16}$ \\
\hline 11 & Thujone & 7.509 & 0.91 & $\mathrm{C}_{10} \mathrm{H}_{16} \mathrm{O}$ \\
\hline 12 & $\begin{array}{l}\text { Bicyclo(3.1)hexan-3-ol,3,-4- } \\
\text { methyl }\end{array}$ & 7.591 & 0.81 & $\mathrm{C}_{10} \mathrm{H}_{18} \mathrm{O}$ \\
\hline 13 & Borneol & 7.925 & 3.38 & $\mathrm{C}_{10} \mathrm{H}_{16} \mathrm{O}$ \\
\hline 14 & P-menth-1-en-8-ol & 8.142 & 1.30 & $\mathrm{C}_{10} \mathrm{H}_{18} \mathrm{O}$ \\
\hline 15 & Champhor & 9.194 & 11.57 & $\mathrm{C}_{10} \mathrm{H}_{16}$ \\
\hline 16 & Bicyclo (3.1.1)heptan-3-one & 9.654 & 0.87 & $\mathrm{C}_{10} \mathrm{H}_{18} \mathrm{O}$ \\
\hline 17 & P-cymen & 9.777 & 5.40 & $\mathrm{C}_{10} \mathrm{H}_{14}$ \\
\hline 18 & $\begin{array}{l}\text { Bicyclo(3.1.1)hept-2-ene-2- } \\
\text { methano }\end{array}$ & 9.876 & 0.36 & $\mathrm{C}_{10} \mathrm{H}_{24}$ \\
\hline 19 & P-menth-1-en- $\beta$-ol & 10.026 & 3.45 & $\mathrm{C}_{10} \mathrm{H}_{18} \mathrm{O}$ \\
\hline 20 & Acetic acid & 10.090 & 0.89 & $\mathrm{C}_{2} \mathrm{H}_{4} \mathrm{O}_{2}$ \\
\hline 21 & Trans-beta terpinyl butanoate & 10.156 & 2.00 & $\mathrm{C}_{14} \mathrm{H}_{24} \mathrm{O}_{2}$ \\
\hline 22 & Caryophyllene & 10.299 & 3.76 & $\mathrm{C}_{15} \mathrm{H}_{24}$ \\
\hline 23 & linalool & 10.466 & 0.79 & $\mathrm{C}_{10} \mathrm{H}_{18} \mathrm{O}$ \\
\hline 24 & $\alpha$-caryophyllene & 10.745 & 0.70 & $\mathrm{C}_{15} \mathrm{H}_{24}$ \\
\hline 25 & Copaene & 11.429 & 0.13 & $\mathrm{C}_{15} \mathrm{H}_{24} \mathrm{O}_{2}$ \\
\hline 26 & menthol & 12.129 & 0.31 & $\mathrm{C}_{10} \mathrm{H}_{20} \mathrm{O}$ \\
\hline 27 & (+)-trans-caryophyllene & 12.548 & 0.08 & $\mathrm{C}_{10} \mathrm{H}_{16}$ \\
\hline 28 & Benzyl alcohol monoterpene $\mathrm{E}$ & 13.172 & 0.05 & $\mathrm{C}_{10} \mathrm{H}_{14} \mathrm{O}_{2}$ \\
\hline 29 & Isobutyl acetate & 13.248 & 0.06 & $\mathrm{C}_{6} \mathrm{H}_{12} \mathrm{O}_{2}$ \\
\hline 30 & Bicycle(3.2.0)-2-one5fomy & 13.605 & 0.07 & $\mathrm{C}_{10} \mathrm{H}_{18} \mathrm{O}$ \\
\hline 31 & Cyclohexane,1,1,2-trimethyl & 13.818 & 0.09 & $\mathrm{C}_{10} \mathrm{H}_{18} \mathrm{O}$ \\
\hline 32 & $(+)$-globulol & 13.974 & 0.12 & $\mathrm{C}_{10} \mathrm{H}_{26} \mathrm{O}$ \\
\hline 33 & Epiglobulol & 14.113 & 2.59 & $\mathrm{C}_{15} \mathrm{H}_{24}$ \\
\hline 34 & Methy(z) 8,11,14 Eicosatrienoate & 14.264 & 0.84 & $\mathrm{C}_{21} \mathrm{H}_{36} \mathrm{O}_{2}$ \\
\hline 35 & (+) Epi bicycles squiphellandrene & 14.468 & 0.22 & $\mathrm{C}_{15} \mathrm{H}_{24}$ \\
\hline 36 & Alpha-Caryophyllene & 14.871 & 0.15 & $\mathrm{C}_{15} \mathrm{H}_{24}$ \\
\hline 37 & $\begin{array}{l}\text { 3-Oxatricyclo- } \\
\text { (4.1.1.0(2.4)octane }\end{array}$ & 15.085 & 0.30 & $\mathrm{C}_{10} \mathrm{H}_{16} \mathrm{O}$ \\
\hline 38 & Humulane-1,2-dien-3-ol & 15.178 & 0.09 & $\mathrm{C}_{15} \mathrm{H}_{24}$ \\
\hline
\end{tabular}




\begin{tabular}{|l|l|c|c|c|}
\hline 39 & Limonene-1,2-epoxide(fr-1) & 15.520 & 0.34 & $\mathrm{C}_{10} \mathrm{H}_{16}$ \\
\hline 40 & $\begin{array}{l}\text { 1-Oxaspiro(2,5)octane,5,5 } \\
\text { dimethyl }\end{array}$ & 15.693 & 1.15 & $\mathrm{C}_{8} \mathrm{H}_{12} \mathrm{O}_{3}$ \\
\hline 41 & 1-Naphthalene propanol & 16.035 & 0.58 & $\mathrm{C}_{15} \mathrm{H}_{24}$ \\
\hline 42 & 5-Hydroxy methyl furfural & 17.344 & 0.07 & $\mathrm{C}_{6} \mathrm{H}_{6} \mathrm{O}_{3}$ \\
\hline
\end{tabular}

\section{Conclusion:}

The findings of this study shows that the salvia officinalis has many importance components, determined that the chemotype, $\alpha$-terpineol (33.07\%), and Champhor (11.57\%) and s.officinalis would serve as good sources of pharmaceutical drugs.

\section{References:}

1-E.A. Safowora, 2008,. Medicinal plant and traditional medicine in Africa, John Wiley and sons Ltd pp1-10.

2-Hamidpour, Hamidpour, S., Hamidpour,M., and Shahlari,M., 2013. Sage: the functional novel medicine for preventing and curing chronic illnesses. International journal of case reportec and images vol.4, pp671-677.

3-Qnais E.Y., Abu- Dieyeh, M., Abdulla, F.A., and Abdalla, S.S., 2010. The antinociceptive and anti-inflammatory effects of salvia officinalis leaf aqueous and butanol extracts. pharm Biol.10 pp1149.

4-A.Y.Leung and S. Foster, 1996. Encyclopaedia of common Natural Ingredients Used in food, Drugs and Cosmetics, John Wiley and sons, New York, NY, USA, $2^{\text {nd }}$ edition.

5-Hamidpour, Hamidpour, R., Hamidpour, S., and Shahlari, M., 2014. Chemistry pharmacology, and Medicinal property of Sage (Salvia) to prevent and cure lllnesses such as obesity, Diabetes, Depression, Dementia, Lupus, Autism, Heart Disease, and cancer. J tradit complement med., Vol 4, pp 82-88.

6-Behradmanesh, S., Derees, F., and Rafieian-kopaei, M., 2013,. "Effect of Salvia officinalis on diabetic patients." J RenInj Prev., vol. 2, pp. 51-54.

7-.Tucker A, Maciarello MJ, 1980,. Howell JT. Botanical aspects of commercial sage. Economic Botany.;34: 16-19.

8- Perry, N. B., Baxter, A. J., Brennan, N. J., Van, K. J. W., Mc, G. J. A., Douglas, M. H., and Joulain, D., 1996. "Dalmatian Sage. Part 1. Differing Oil Yields and Compositions from Flowering and Non-Flowering Accessions." Flavour Frag. J., vol. 11, pp. 231-238.

9-Putievsky, E., Ravid, U., and Sanderovich, D., 1992. "Morphological observations and essential oils of sage (Salvia officinalis L.) under cultivation." J Essent Oil Res., vol. 4, pp. 291-293.

10-Pace, L. and Piccaglia, R., 1995. "Characterization of the essential oil of the wild Italian endemic sage Salvia officinalis L. var. angustifolia Ter. (Labiatae)." J. Essent. Oil Res., vol. 7, pp. 443-446.

11-Piccaglia, R. and Marotti, M., 1993. "Characterization of several aromatic plants grown in northern Italy." Flavour Frag J., vol. 8, pp. 115-122.

12-Edris, A. E., Jirovetz, L., Buchbauer, G., Denkova, Z., Slavchev, A., and Stoyanova, A., 2007. "Chemical composition, antimicrobial activities and olfactrive evaluation of 
Salvia officinalis L. (sage) essential oil from Egypt." J Essent Oil Res., vol. 19, pp. 186189.

13-El, o. Y., Bouyanzer, A., Majidi, L., Paolini, J., Desjobert, J. M., Costa, J., Chetouani, A., and Hammout, B., 2014. "Salvia officinalis essential oil and the extract as green corrosion inhibitor of mild steel in hydrochloric acid." Journal of Chemical and Pharmaceutical Research, vol. 6, pp. 1401-1416.

14-Fellah, S., Romdhane, M., and Abderraba, M., 2006. "Extraction et étude des huiles essentielles de la Salvia officinalis L. cueillie dans deux régions différentes de la Tunisie." J. Soc. Alger. Chim., vol. 16, pp. 193-202. 